\title{
A Comparative Study on the Properties of Mangrove and Non - Mangrove Soils of Sundarbans, West Bengal, India
}

\author{
Dasgupta $\mathbf{M}^{1 *}$, Ghosh $\mathrm{A}^{2}$ and Naskar $\mathrm{KR}^{3}$ \\ ${ }^{1}$ Eutech Scientific Services, USA \\ ${ }^{2}$ Departmen of Botany, University of Burdwan, India \\ ${ }^{3}$ Central Inland Fisheries Research Institute, India
}

\section{Research article \\ Volume 3 Issue 2}

Received Date: February 18, 2018

Published Date: February 23, 2018

*Corresponding author: Manjistha Dasgupta, Eutech Scientific Services, Highland Park, New Jersey, USA 07869, Tel: 8624859902; Email: manjisthad@yahoo.com

\begin{abstract}
Substrate characteristics are important determining factors that control the community structure and growth of mangrove ecosystem. On the other hand, occurrence of mangrove vegetation may also exert considerable influence on nature and properties of coastal saline soils. In view of this interdependence of mangrove vegetation and their habitats, a comparative study was carried out to assess the difference between mangrove soils and their adjacent ones which were devoid of mangrove vegetation. It has been hoped that the study would be helpful in generating a gross idea about the nature and properties of mangrove soils with relation to the non-mangrove coastal saline soils of Sundarbans. During this study, soil samples were collected from a mangrove dominated and an adjacent without mangrove soil in ten locations in Sundarban Island. The collected samples were analyzed for different soil properties between mangrove and nonmangrove soils..
\end{abstract}

Keywords: Mangrove and non-mangrove soil of Indian Sundarbans; Soil chemistry

Abbreviations: EC: Electrical Conductivity; OC: Organic Carbon; CEC: Cation Exchange Capacity

\section{Introduction}

At the mouth of the Ganga - Brahmaputra river system, Sundarbans represents one of the largest single chunk of mangrove forest within the latitude $21^{\circ} 31^{\prime}$ and $22^{\circ} 30$ / North and longitude $88^{\circ} 10$ / and $89^{\circ} 51 /$ East. Mangrove ecosystems are the hot spots of biological diversity in the form of many varieties of flora and fauna. These are one of the important types of natural wetlands found in the inter-tidal zone of tropical and sub-tropical regions of the world [1-3]. They also exhibit self - generating and selfmaintaining littoral plant formation often constituting a dynamic ecosystem inhabited by a complex assemblage of flora and fauna. Mangrove forests can be very productive and their food chains and nutrient cycles are closely linked to the adjacent coastal waters $[4,5]$. The mangrove ecosystems depend heavily on various important environmental factors such as climate, tides, water current, salinity, dissolved oxygen, soil - water nutrients status etc. This ecosystem is basically an open ecosystem, which exchanges matter and energy with adjacent marine, freshwater and terrestrial ecosystems. India has about 3.1 Mha of coastal soils including the area covered by 
mangrove forest [6]. Mangroves are abundant in broad, sheltered and low lying coastal plants where topographic gradients are small and tidal amplitudes are large. Repeatedly flooded but well drained soils support good mangrove growth and high species diversity [7]. Mangrove vegetation depends upon the soil structure and soil characteristics and also the growth and nutrition of mangrove vegetation are greatly influenced by soil properties. Nutrient fluxes in this environment are intricately related to plant assimilation and microbial mineralization [5,8]. Nutrient availability may limit growth and production in many mangals. Varying nutrient concentration can also change competitive balances and affect species distributions [9]. As a result, nutrient pulses can create immediate and impressive changes in the vegetation. For example, on the south - east coast of India, high nutrient concentration and low salinity from monsoons produce rapid growth in the mangroves. It was reported by Kaly, et al. [10] that the loss of nitrogen and phosphorus from the soil cause an adverse effect on mangrove vegetation. Salinity also has profound influence on the productivity and growth of mangrove vegetation. The distribution of plant species within the mangals in many cases is controlled by the salinity gradients [11,12]. This type of salinity based zonation is very prominent in the north - east coast of Bay of Bengal and the adjacent Hugli estuary.

\section{Methodology}

The soil samples were collected from mangrove and non- mangrove area of Indian Sundarbans. The collection of soil samples and the work done occurred in three phases. The soil samples were collected using standard methodology [13]. In the Sundarbans, the rooting pattern is found to reach, on an average, a little higher up than $90 \mathrm{~cm}$. During the present study, therefore, profile pits were excavated till $90 \mathrm{~cm}$ depth, which was considered to be deep enough to reveal the principal features effecting plant growth. The soil samples were collected from different point of a particular area. At least 3 replicates were sampled so as to ensure more or less uniform and representative soil sampling. After collection, all the subsamples were put in a clean polythene sheet and mixed the soil samples thoroughly. Then the soil samples were divided into four parts, from these, two of them were removed and remaining two portions were mixed again. After that some amounts of soil were discarded and about $1 \mathrm{~kg}$ of soil for each sample was retained for the further analysis. Along with the variation of soil, the profile depth and landscape areas were also kept in mind.
During this phase of the study, soil samples were collected from one mangrove dominated and one adjacent without mangrove soils in ten locations under Sundarbans. The collected soil samples were analyzed for different soil properties for assessing the specific variations in such properties between mangrove and nonmangrove soils.

The collected soil samples were air dried at a temperature of about $25^{\circ}-30^{\circ} \mathrm{C}$ and relative humidity of about $20 \%-60 \%$ in the laboratory. This was ground with the help of wooden mortar to pass initially through $2 \mathrm{~mm}$ size sieve and finally through 80 mesh size sieve. The standard methods adopted for these analyses are as follows:

\section{Analysis of Soil Samples}

The Standard Methods adopted for these analyses are as follows:

\section{pH}

$\mathrm{pH}$ was analyzed by potentiometric method using a $\mathrm{pH}$ Meter, which directly gives readings after proper calibration. The soils were subjected to shaking with distilled water at 1:2 ratio for about half an hour after which $\mathrm{pH}$ was determined with the help of an electrically operated $\mathrm{pH}$ meter [13].

\section{Electrical Conductivity (EC)}

Electrical conductivity was measured from the same soil: water extracts i.e 1:2 ratio of the soil samples, as was used for $\mathrm{pH}$ estimation.

\section{Salinity}

$\mathrm{Cl}$ - ions can be conveniently estimated by titration with silver nitrate $\left(\mathrm{AgNO}_{3}\right)$ in the presence of chromate ions.

\section{Organic Carbon (OC)}

The rapid titrimetric method of Walkley \& Black [14] using heat of dilution was used for determination of organic carbon in soils. It influences various physicochemical properties of the soil including release of different nutrients to more available form. This method has an advantage that it excludes less active elementary carbon of soil (e.g. graphite) and includes only that part of OC.

\section{Nitrogen}

Available nitrogen: The amount of $\mathrm{N}$ under easily mineralizable form was determined by oxidizing the soil 
organic matter with mild oxidizing agents so that only the easily mineralizable forms of organic nitrogen are oxidized. 0.32 percent potassium permanganate $\left(\mathrm{KMnO}_{4}\right)$ is commonly used for this purpose [15].

Total nitrogen: It was determined by Kjeldahl digestion and distillation method [13].

\section{Cation Exchange Capacity (CEC)}

The total quantity of cations which a soil can absorb by cation exchange is termed as Cation Exchange Capacity (CEC) of the soil and is expressed as milliequivalent per $100 \mathrm{~g}$ of soils [16].

\section{Exchangeable Sodium and Potassium}

Exchangeable $\mathrm{Na}^{+}$and $\mathrm{K}^{+}$extracted with neutral normal ammonium acetate $\left(\mathrm{CH}_{3} \mathrm{COONa}\right)$ by standard procedure [13].

\section{Available Phosphorus}

The available phosphorous was estimated by using Olsen's sodium bicarbonate extractable method due to the alkaline nature of the soils in the Indian Sundarbans [17].

\section{Results and Discussion}

General properties of the mangrove soils and their nearby non-mangrove ones in Sundarbans have been presented in Tables 1-9. Although electrical conductivity values of coastal saline soils in Table 1 vary widely at different seasons depending on precipitation and evaporation [18], comparison of two kinds of soils at a particular location on a point of time was expected to provide usable information on this property. As observed from Table 4, all the soils under both the systems exhibited high electrical conductivity (EC) values, obviously owing to being situated in an estuarine area. However, it was interesting to observe that in spite of being situated under inter tidal zones receiving highly saline estuarine water at frequent intervals; the average EC values of the mangrove soils were marginally lower than the non-mangrove soils. This behavior was attributed to the fact that the non-mangrove soils occurred mostly in slightly higher elevations and under more dry conditions. This dryness of non-mangrove soils was due to regular evaporation of the soil-water from the surface area leading to increased capillary movement of the highly saline ground water from lower levels to surface soils [18]. This upward movement of saline water and consequent evaporation of water from the soil surface resulted in increased salt content of the nonmangrove soils. On the other hand, the soils under mangrove zones were subjected to regular inundation by tidal water and maintained equilibrium with the salinity of the estuarine water. However, when analyzed statistically, one variation did not appear to be significant (Table 9).

Similar observations could be found for total salt content also (Table 2). As stated for EC, the non-mangrove soils showed slightly higher levels of salinity as compared to the mangrove soils. Reasons of such behavior have been discussed earlier. As observed for EC, salinity values also did not show statistically significant variations for mangrove and non-mangrove soils (Table 9).

$\mathrm{pH}$ values of both the kinds of soils varied within narrow ranges, between 7.4 to 8.2 for mangrove soils and 7.5 - 8.4 for non-mangrove soils with respective average of 7.8- 8.0 (Table 3). Such alkaline $\mathrm{pH}$ values in coastal saline soils of Sundarbans is well documented and the behavior may be attributed to high salt content of these soils $[19,20]$. However, the variations in $\mathrm{pH}$ values in both the kinds of soils were found to be limited. This behavior was probably due to buffering action of estuarine water preventing large scale variations in $\mathrm{pH}$ values, as has been described by Reid [21]. As a result, the variations in $\mathrm{pH}$ in these two soil groups did not appear to be statistically significant (Table 9).

Organic Carbon content of the mangrove soils was comparatively higher than the non-mangrove soils (Table 4). This behavior was attributed to accumulation of leaf litters and other plant residues in the mangrove soils. However, such accumulation of organic materials was likely to be reduced to some extent by the tidal water which tended to washout a large share of the organic residues from the mangrove area thus narrowing the difference between the organic carbon contents of mangrove and non-mangrove soils. In spite of this behavior, the differences in organic carbon status of mangrove and non-mangrove soils were found to be statistically significant (Table 9).

In the present study, the mangrove soils appeared to exhibit considerably higher CEC values as compared to the non-mangrove soils (Table 5). This behavior could be largely attributed to occurrence of higher amount of organic matter in the mangrove soils. However, as compared to the variations in organic carbon values, differences in CEC in mangrove soils were comparatively larger. Probably, occurrence of the slightly higher percentage of finer particles in mangrove soils might have increased the CEC values of mangrove soils in addition to the effects of organic matter in such soils. The variation in cation exchange capacity in mangrove and non-mangrove 
soils also appeared to be statistically significant (Table 9), as was found in case of organic carbon also. Such increased cation exchange capacity in mangrove soils is likely to benefit such soils in holding different cationic nutrients in easily available forms and to benefit the mangrove vegetation growing in these soils.

Available nitrogen status was marginally higher in mangrove soils Table 6 . This behavior was also attributed to higher organic $\mathrm{C}$ content of these soils. As compared to the difference in organic matter content of mangrove and non-mangrove soils, the variations in available nitrogen status between these two kinds of soils were found to be smaller and was not found to be statistically significant Table 9. While washing away of a good part of mineralized nitrogen by tidal water may be a major cause of such lowering in differences, slower rate of mineralization of nitrogen from organic to mineral form under saline environment [22] may be another reason for such behavior.

Almost similar was the situation for available phosphorus also. Mangrove dominated soils exhibited higher availability of this nutrient, as compared to the soils without mangroves Table 7 . The difference was however, more prominent than nitrogen. The higher rate of accumulation of organic matter in mangrove soils probably resulted in increased availability of phosphorus in such soils. In addition, phosphorus being more strongly bound with soil particles than nitrogen, possibility of washing of the available phosphorus from the mangrove soils was not so high as was in case of mineralized nitrogen [23]. This resulted in significantly higher occurrence of phosphorus in available form in mangrove soils (Table 9), which may be considered to be beneficial for maintaining their productivity.

Status of the exchangeable potassium was high in both the soil groups (Table 8). Among them, however, mangrove soils showed comparatively higher concentrations than the non-mangrove soils. Increased cation exchange capacity in mangrove soils has been discussed earlier. This behavior probably helped to hold more amount of potassium in soil exchange complex and tended to increase the amount of potassium in exchangeable form in the mangrove soils. However, the variation in exchangeable potassium content in mangrove and non-mangrove soils was not statistically significant (Table 9).

The study thus indicated that occurrence of mangrove vegetation tends to exert considerable influence on nature and properties of coastal saline soils as compared to their counter parts without mangroves. Of the studied properties, variations in organic carbon content, cation exchange capacity and availability of phosphorus were statistically significant in mangrove and non-mangrove soils. Most of the effects on different physical and chemical properties appeared to be beneficial for soil quality as well as plant growth and are likely to be beneficial, in turn, for the development of euryhaline mangroves in these soils.

\begin{tabular}{|c|c|c|c|}
\hline \multirow{2}{*}{ Sl. No. } & \multirow{2}{*}{ Location } & \multicolumn{2}{|c|}{ Electrical conductivity (dsm-1) } \\
\cline { 2 - 4 } & & Mangrove & Non-mangrove \\
\hline 1 & Canning & 18.4 & 19.3 \\
\hline 2 & Masjidbati & 18.4 & 21 \\
\hline 3 & Piyali & 18.6 & 33.1 \\
\hline 4 & Gosaba & 29.5 & 23 \\
\hline 5 & Kulpi & 19 & 22.2 \\
\hline 6 & Joygopalpur & 19.2 & 23 \\
\hline 7 & Sagar Island & 20.2 & 37.2 \\
\hline 8 & Bakkhali & 18.5 & 33.1 \\
\hline 9 & Jharkhali & 36.4 & 25.9 \\
\hline 10 & Basanti & 27.5 & 22.6 \\
\hline
\end{tabular}

Table 1: Electrical conductivity values of some mangrove and nearby non-mangrove soils of Sundarbans. 


\section{Advances in Clinical Toxicology}

\begin{tabular}{|c|c|c|c|}
\hline \multirow{2}{*}{ Sl. No. } & \multirow{2}{*}{ Location } & \multicolumn{2}{|c|}{ Soil Salinity (ppt) } \\
\cline { 3 - 4 } & Canning & Mangrove & Non-mangrove \\
\hline 1 & Masjidbati & 11.5 & 12 \\
\hline 2 & Piyali & 11.6 & 12.2 \\
\hline 3 & Gosaba & 11.8 & 12.4 \\
\hline 4 & Kulpi & 17.7 & 13.2 \\
\hline 5 & Joygopalpur & 11.9 & 13.1 \\
\hline 6 & Sagar Island & 12.9 & 19.2 \\
\hline 7 & Bakkhali & 11.9 & 19 \\
\hline 8 & Jharkhali & 22.7 & 23.2 \\
\hline 9 & Basanti & 16.8 & 17.4 \\
\hline 10 & Average & 14.1 & 16.1 \\
\hline
\end{tabular}

Table 2: Salt content values of some mangrove and nearby non-mangrove soils of Sundarbans.

\begin{tabular}{|c|c|c|c|}
\hline \multirow{2}{*}{ Sl. No. } & \multirow{2}{*}{ Location } & \multicolumn{2}{|c|}{ Soil pH } \\
\cline { 2 - 4 } & & Mangrove & Non-mangrove \\
\hline 1 & Canning & 8 & 8.2 \\
\hline 2 & Masjidbati & 7.7 & 8.1 \\
\hline 3 & Piyali & 8 & 8.2 \\
\hline 4 & Gosaba & 8 & 7.7 \\
\hline 5 & Kulpi & 7.5 & 7.5 \\
\hline 6 & Joygopalpur & 7.4 & 8.1 \\
\hline 7 & Sagar Island & 8.1 & 8.4 \\
\hline 8 & Bakkhali & 8.2 & 8.3 \\
\hline 9 & Jharkhali & 8.2 & 7.7 \\
\hline 10 & Basanti & 7.4 & 8 \\
\hline
\end{tabular}

Table 3: pH values of some mangrove and nearby non-mangrove soils of Sundarbans.

\begin{tabular}{|c|c|c|c|}
\hline \multirow{2}{*}{ Sl. No. } & \multirow{2}{*}{ Location } & \multicolumn{2}{|c|}{ Organic carbon (\%) } \\
\cline { 3 - 4 } & & Mangrove & Non-mangrove \\
\hline 1 & Canning & 1 & 0.9 \\
\hline 2 & Masjidbati & 1.2 & 0.9 \\
\hline 3 & Piyali & 1.2 & 0.9 \\
\hline 4 & Gosaba & 1.4 & 0.9 \\
\hline 5 & Kulpi & 1 & 0.7 \\
\hline 6 & Joygopalpur & 1.1 & 0.7 \\
\hline 7 & Sagar Island & 1 & 0.7 \\
\hline 8 & Bakkhali & 0.9 & 0.6 \\
\hline 9 & Jharkhali & 1.1 & 0.5 \\
\hline 10 & Basanti & 0.9 & $\mathbf{0 . 8}$ \\
\hline
\end{tabular}

Table 4: Organic carbon values of some mangrove and nearby non-mangrove soils of Sundarbans. 


\begin{tabular}{|c|c|c|c|}
\hline \multirow{2}{*}{ Sl. No. } & \multirow{2}{*}{ Location } & \multicolumn{2}{|c|}{ Cation exchange capacity (me g-2 } \\
\cline { 3 - 4 } & & Mangrove & Non-mangrove \\
\cline { 3 - 4 } & Canning & 81.5 & 62.5 \\
\hline 1 & Masjidbati & 84.9 & 66.8 \\
\hline 2 & Piyali & 80.6 & 59.7 \\
\hline 3 & Gosaba & 86.7 & 66.6 \\
\hline 4 & Kulpi & 83.9 & 58.4 \\
\hline 5 & Joygopalpur & 82.8 & 57.2 \\
\hline 6 & Sagar Island & 81.7 & 54.9 \\
\hline 7 & Bakkhali & 80.8 & 51 \\
\hline 8 & Jharkhali & 80.1 & 53.4 \\
\hline 9 & Basanti & 81.8 & 55.5 \\
\hline 10 & Average & 82.5 & 58.6 \\
\hline
\end{tabular}

Table 5: Cation exchange capacity values of some mangrove and nearby non-mangrove soils of Sundarbans.

\begin{tabular}{|c|c|c|c|}
\hline \multirow{2}{*}{ Sl. No. } & \multirow{2}{*}{ Location } & \multicolumn{2}{|c|}{ Available nitrogen (mg kg-1) } \\
\cline { 2 - 3 } & & Mangrove & Non-mangrove \\
\hline 1 & Canning & 81.5 & 88.8 \\
\hline 2 & Masjidbati & 90.7 & 86.2 \\
\hline 3 & Piyali & 89.1 & 87.1 \\
\hline 4 & Gosaba & 101.8 & 73.5 \\
\hline 5 & Kulpi & 83.5 & 79.6 \\
\hline 6 & Joygopalpur & 86.7 & 77.8 \\
\hline 7 & Sagar Island & 77 & 79.1 \\
\hline 8 & Bakkhali & 72.6 & 75.4 \\
\hline 9 & Jharkhali & 80.1 & 66.1 \\
\hline 10 & Basanti & 70.6 & 80.1 \\
\hline
\end{tabular}

Table 6: Available nitrogen values of some mangrove and nearby non-mangrove soils of Sundarbans.

\begin{tabular}{|c|c|c|c|}
\hline \multirow{2}{*}{ Sl. No. } & \multirow{2}{*}{ Location } & \multicolumn{2}{|c|}{ Available phosphorus (mg kg-1) } \\
\cline { 3 - 4 } & & Mangrove & Non-mangrove \\
\hline 1 & Canning & 20.1 & 14.1 \\
\hline 2 & Masjidbati & 18 & 12.7 \\
\hline 3 & Piyali & 18.6 & 12.4 \\
\hline 4 & Gosaba & 21.6 & 12.5 \\
\hline 5 & Kulpi & 18.3 & 12.6 \\
\hline 6 & Joygopalpur & 20.8 & 13.1 \\
\hline 7 & Sagar Island & 20.5 & 12.1 \\
\hline 8 & Bakkhali & 19.2 & 12.3 \\
\hline 9 & Jharkhali & 16.5 & 12.4 \\
\hline 10 & Basanti & 15.8 & 13.3 \\
\hline
\end{tabular}

Table 7: Available phosphorus values of some mangrove and nearby non-mangrove soils of Sundarbans. 


\section{Advances in Clinical Toxicology}

\begin{tabular}{|c|c|c|c|}
\hline \multirow{2}{*}{ S1. No. } & \multirow{2}{*}{ Location } & \multicolumn{2}{|c|}{ Exchangeable Potassium (meq/100g soil) } \\
\cline { 2 - 4 } & & Mangrove & Non-mangrove \\
\cline { 2 - 4 } & Canning & 15 & 14.1 \\
\hline 1 & Masjidbati & 24.8 & 17.6 \\
\hline 2 & Piyali & 28.6 & 20 \\
\hline 3 & Gosaba & 30.2 & 23.6 \\
\hline 4 & Kulpi & 23.3 & 20.2 \\
\hline 5 & Joygopalpur & 21.4 & 17.5 \\
\hline 6 & Sagar Island & 18.3 & 18.6 \\
\hline 7 & Bakkhali & 17.8 & 19.9 \\
\hline 8 & Jharkhali & 20 & 13.2 \\
\hline 10 & Basanti & 16.4 & 18.4 \\
\hline
\end{tabular}

Table 8: Exchangeable Potassium values of some mangrove and nearby non-mangrove soils of Sundarbans.

\begin{tabular}{|c|c|c|c|}
\hline Sl. No. & Soil properties & t values & Conclusion \\
\hline 1 & PH & -1.2366 & NS \\
\hline 2 & EC & -1.18 & NS \\
\hline 3 & Salinity & -1.16 & S \\
\hline 4 & CEC & 13.13 & S \\
\hline 5 & Organic carbon & 4.8 & NS \\
\hline 6 & Av. Nitrogen & 0.89 & SS \\
\hline 7 & Av. Phosphorus & 6.61 & NS \\
\hline 8 & Ex. Potassium & 1.21 & NS \\
\hline 8 & Sand & -0.94 & 1.57 \\
\hline
\end{tabular}

NS = Non Significant, $\mathrm{S}=$ Significant at $5 \%$ level

Table 9: Test of significance ( $t$ test) for different properties of mangrove and non-mangrove soils in Sundarbans.

\section{Acknowledgement}

We are grateful to the Indian Council of Agricultural Research New Delhi for providing the necessary grants under National Fellow Project.

\section{References}

1. Tomlinson PB (1986) The Botany of mangroves (Cambridge tropical biology series). Cambridge University Press, Cambridge.

2. Duke NC (1992) Mangrove floristic and biogeography. In: Robertson AI, et al. (Eds.), Coastal and Estuarine studies: Tropical Mangrove Ecosystems, Washington, USA, Amer Geol Union 41, pp: 63-100.

3. Ricklets RE, RE Latham (1993) Global patterns of diversity in mangrove floras. In: R.E. Ricklefs, et al. (Eds.), Species Diversity in Ecological Communities.
Historical and Geographical Perspectives, University of Chicago Press, Chicago, pp: 215-233.

4. Clough BF (1992) Primary productivity and growth of mangrove forests. In: Robertson AI, et al. (Eds.), Coastal and Estuarine studies: Tropical Mangrove Ecosystems. Washington, USA, Amer Geol Union pp: 225-249.

5. Alongi DM (1996) The dynamics of benthic nutrient pools and fluxes in tropical mangrove forests. Jour Mar Res 54(1): 123-148.

6. Yadav JSP, Bandopadhyay AK, Bandyopadhyay BK (1983) Extent of coastal saline soils of India. J Indian Soc Coastal agric Res 1(1): 1-6.

7. Azariah J, Azariah H, Gunasekaran S, Selvam V (1992) Structure and species distribution in Coringa mangrove forest. Godaveri Delta, Andhra Pradesh, India. Hydrobiologia 247(1-3): 11-16. 


\section{Advances in Clinical Toxicology}

8. Middelburg JJ, Nieuwenhuize J, Slim FJ, Ohowa B, (1996) Sediment biogeochemistry in south East African mangrove forest (Gazi Bay, Kenya). Biogeochemistry 34(3): 133-155.

9. Chen R, Twilley RR (1998) A gap dynamic model of mangrove forest development along gradients of soil salinity and nutrient resources. J of Ecology 86(1): 3751.

10. Kaly UL, Eugelink G, Robertson AI (1997) Soil conditions in damaged North Queensland mangroves. Estuaries 20(2): 291-300.

11. Ukpong IE (1994) Soil-vegetation interrelationships of mangrove swamps as revealed by multivariate analyses. Geoderma 64(1-2): 167-181.

12. Ball MC (1998) Mangrove species richness in relation to salinity and water logging; a case study along the Adelaide River floodplain, northern Australia. Global Ecology and Biogeography Letters 7(1): 73-82.

13. Jackson ML (1973) Soil Chemical Analysis. Prentice Hall Pubbl, New Delhi.

14. Walkley A, Black IA (1934) An examination of Degtjareff method for determining soil organic matter and a proposed modification of the chromic acid titration method. Soil Sci 37(1): 29-37.

15. Subbiah B, Asija GL (1956) A rapid procedure for estimation of available nitrogen in soils. Current Science 25(8): 259.
16. USDA (1961) The yearbook of Agriculture, 87th Congress $1^{\text {st }}$ Session, House Document No 29.

17. Olsen SR, Cole CV, Watanabe FS, Dean LA (1954) Estimation of available phosphorus in soils by extraction with sodium bicarbonate. Circular, Washington DC: US Department of Agriculture 939: 19

18. Yadav JSP, Sinha TS, Bandyopadhyay AK, Rao KVGK, Biswas CR (1979) Coastal saline soils of India. Bull No. 5, CSSRI, Karnal, pp: 34.

19. Bandyopadhyay AK, Sarkar D (1987) Occurrence of acid saline soils in coastal Sundarbans area of West Bengal. Journal of Indian Society of Soil Science 35: 542-544.

20. Mandal LN, Chattopadhyay GN (1987) Chemistry of coastal saline soils in relation with brackishwater aquaculture. J Indian Soc Coastal Agric Res 5(1): 353359.

21. Reid GK (1961) Ecology of Inland Waters and Estuaries. Reinhold Publishing Corporation, New York.

22. Chattopadhyay GN, Mandal LN (1980b) Effect of different levels of water salinity on the decomposition of organic manures in brackishwater fish pond soil. Hydrobiologia 72(3): 287-292.

23. Brady C, Nyle (1980) Nature and Properties of Soils. Eurasia Publ New Delhi. 